\title{
구름접촉피로시험을 통한 고속철도 레일연마량 분석 \\ Analysis for Optimal Rail Grinding Amount by Rolling Contact Fatigue Test in High Speed Railway
}

\author{
성덕룡 ${ }^{1 \dagger} \cdot$ 장기성 ${ }^{2} \cdot$ 박용걸 $^{2}$ \\ Deok-Yong Sung $\cdot$ Ki-Sung Chang $\cdot$ Yong-Gul Park
}

\begin{abstract}
The rail surface defects which are generated on repeated rolling contact fatigue are getting increased according to high speed, high density, and minimum weight. In addition, Increasing noise and vibration are affected by these also impact load generated as well. Because of this phenomenon, more serious and critical damages were occurred. In fact, in order to control them, the rail grinding amount in Korea. This study evaluated how depth of hardening on rail surface is formed and suggested optimal rail grinding amount by RCF(rolling contact fatigue) test with generated contact pressure between KTX wheel and UIC60 rail by applying FEM analysis. Therefore, the amount was generated approximately $0.2 \mathrm{~mm} / 20 \mathrm{MGT}$ to maintain integrity of rail surface by getting rid of depth of hardening on rail according to rail accumulated passing tonnage.
\end{abstract}

Keywords : Rolling contact fatigue, Hardness, Grinding, Contact pressure

초 록 차륜과 레일의 반복적인 구름접촉은 레일 표면결함을 유발하고, 레일 표면결함은 충격하중을 유발하여 소음·진동, 레일파단, 궤도파괴로 이어지고 심할 경우 열차사고(탈선)를 발생할 수 있다. 이러한 레일 표면결함 을 제어하기 위한 방법으로 레일연마가 시행되고 있다. 본 연구는 KTX차륜과 UIC레일에서 발생하는 최대 접촉 압력을 유한요소해석을 통해 산정하였고, 일반레일 및 열처리레일에 대한 구름접촉피로시험을 수행하여 접촉압 력 및 반복횟수에 따른 레일표면 경화층 형성 경향을 분석하였으며, 누적통과톤수에 따라 고속철도 레일에서 발 생하는 표면 경화층을 제거하여 건전한 레일표면을 유지하기 위해 $0.2 \mathrm{~mm} / 2$ 천만톤의 적정 레일연마량을 제안하 였다.

주요어 : 구름접촉피로, 경도, 레일연마, 접촉압력

\section{1. 서 론}

일반적으로 구름접촉피로 및 마모는 레일과 차륜의 반복 적인 접촉에 의해 발생되는 현상으로 차량의 고속화를 위해 지속적인 연구가 진행되고 있다. 철도 차량의 고속화는 전 세계적인 추세이며, $300 \mathrm{~km} / \mathrm{h}$ 이상의 속도로 주행 가능한 차 량이 계속적으로 개발되고 있고 국내에서는 최고속도 $430 \mathrm{~km} /$ $\mathrm{h}$ 의 차세대 고속열차를 개발중에 있다. 하지만 차량의 고속 화에 따른 접촉압력의 증가는 레일표면의 구름접촉 피로손 상의 발생빈도를 높게하고, 이러한 레일의 손상은 승차감, 소 음, 주행 안정성과 밀접한 연관이 있어 매우 중요하게 다루 어지는 요소이다. 이에 따라, 레일손상을 예방하고 제어하기 위해 국내외에서는 레일 탐상차 및 종합검측차 운행과 레일 연마기준 및 교체기준을 마련하여 운영하고 있다[1]. 특히, 국외 철도선진국의 경우 경제성, 유지보수효율성 등을 고려 하여 주기적인 레일연마를 시행하고 있으며, 자체 운영환경

$\dagger$ †교신저자 : 대원대학교 철도건설과

E-mail : dysung@mail.daewon.ac.kr

${ }^{1}$ 대원대학교 철도건설과

${ }^{2}$ 서울과학기술대학교 철도전문대학원
을 고려한 레일연마기준을 수립하여 적용하고 있다. 국내의 경우에는 도시 및 고속철도에서 국외 기준들을 초기에 준용 하여 사용하였으나, 실제 현장에서 발췌한 레일의 심부대비 경도 분석을 통해 레일연마주기 및 연마량을 제시한 바 있 다[1,3,4].

일본 신간선에서는 레일 교체수량 중 쉘링(shelling), 스쿼 트(squats), 헤드체크(head check)가 약 $70 \%$ 를 차지하였으며 [2], 쉘링 발생메커니즘을 분석하였는데 약 4천만톤의 통과 톤수에서 얇은 판(dent)이 형성된 후 약 1 억톤에서 내부로 진전된 가지균열(micro branch)이 형성되었고, 약 3 4억톤에 서 횡방향 균열로 진전되는 경향이 나타남에 따라 레일연마 주기를 4 천만톤당 1 회 실시하는 것으로 하였다[2]. 또한, 일 본 RTRI연구소에서는 차륜/레일 구름접촉피로시험을 통해 레일교체주기인 8억톤 이상까지 구름접촉피로손상 없이 레 일을 사용하기 위해서는 레일연마주기를 $0.1 \mathrm{~mm} / 5$ 천만톤으 로 제시하였으며[2], Kim 등[3]과 Sung 등[4]은 사용개월수 에 따른 레일시험편에 대한 경도측정결과를 심부대비 경도 에 대하여 분석한 후 레일표면 경도가 심부대비 95 110\% 수준을 유지하도록 레일연마주기 및 깊이를 제시한 바 있다.

본 연구에서는 실제 KTX 동력차 차륜과 UIC60레일의 동 
일한 크기와 물성치로 ABAQUS를 이용하여 모델링 한 후, 정적윤중과 KTX $300 \mathrm{~km} / \mathrm{h}$ 에 대한 동적윤중을 차륜의 접촉 위치별 접촉압력을 산정하였으며, 산정된 접촉압력을 적용 한 구름접촉피로시험(RCF, Rolling Contact Fatigue Test)을 통해 구름접촉피로에 따른 표면경화 정도를 분석하여 일반 및 열처리레일에 대한 적정 연마량을 분석하고자 하였다.

\section{2. 수치해석}

\section{1 차륜/레일 구름접촉피로 메커니즘}

철도선로는 레일과 차륜간에 접촉면적이 작고 마찰계수가 작아 전동저항이 적은 것이 장점이다. 그러나 이 작은 접촉 면적에서 $1,000 \mathrm{kN} / \mathrm{mm}^{2}$ 이상의 높은 응력이 발생함에 따라 차륜과 레일의 소성변형을 일으킬 수 있다[5]. 레일표면에서 발생하는 손상(flakes, cracks)은 가속 및 감속에 의해 발생 하는 접선력(slip)과 수직력(adhesion)의 변화로 인하여 주로 발생하며 차륜과 레일의 구름접촉에 의해 변형이 확장되어 진행된다. Fig. 1은 차륜의 구름접촉에 의해 레일표면의 소 성변형으로 발생하는 손상메커니즘을 보여준다.

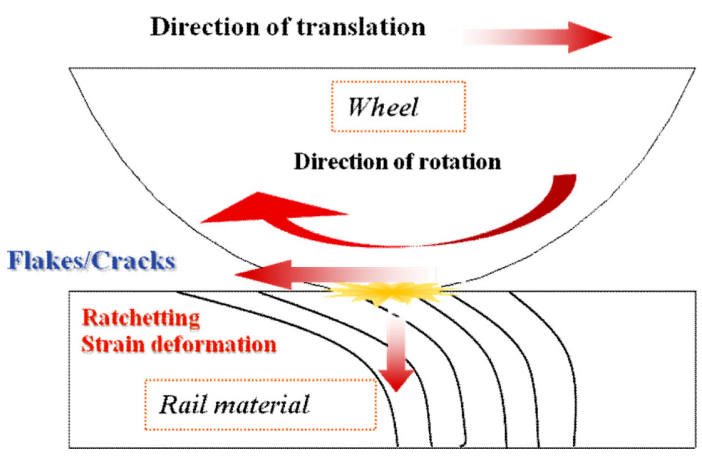

Fig. 1 Rail damage mechanism on rolling contact fatigue

\section{2 차륜/레일 접촉위치에 따른 레일표면 접촉압력 산정}

\subsubsection{FEM 해석}

차륜-레일 접촉 시 발생하는 접촉압력 해석방법은 현재까 지 Hertz이론[5]이 사용되고 있지만, Hertz이론은 차륜 및 레 일의 변형을 고려 할 수 없을 뿐만 아니라 레일 게이지 코 너에서의 접촉해석에 대한 결과를 얻기 어려운 단점이 있다. 즉, 레일의 게이지 코너 접촉영역에서 차륜과 레일의 프로 파일 곡률 변화가 상당히 크고, 접촉영역의 크기가 게이지 코너영역에 비해 작지 않기 때문에 반 무한체 가정은 유효 하지 않다. 반면, 유한요소해석은 접촉부위의 형상이 일정한 곡률을 가졌다고 가정하지 않고 실제 기하학적 형상을 모델 링함으로써 더 정확하게 두 물체의 접촉 거동을 모사하고, 차륜과 레일의 접촉점이 두개 이상인 경우(다중 접촉, multi point contact)를 고려할 수 있으며, 재료의 소성변형 등의 모 사가 가능하다[6]. Table 1에서는 모델링 방법 및 해석조건, $\mathrm{KTX}$ 동력차 차륜과 UIC60레일을 모델링한 형상을 나타낸다.

또한, 직선부 주행 시 발생하는 사행동은 차륜과 레일의 접
Table 1 Modeling method and requirements for FEM analysis

\begin{tabular}{c|c|c}
\hline \hline Model & Input data & remark \\
\hline \hline Element & $\begin{array}{c}\text { Wheel of KTX } \\
\text { UIC60 rail }\end{array}$ & $\begin{array}{c}\text { Slope of wheel : 1/40 } \\
\text { Slope of rail : 1/20 } \\
\text { Modulus of } \\
\text { elastic }\end{array}$ \\
\hline Load & $\begin{array}{c}\text { Static load of wheel : 85kN } \\
\text { Dynamic load of wheel* } \\
138 \mathrm{kN}\end{array}$ & $\begin{array}{c}\text { Minimum length: } \\
1 \sim 2 \mathrm{~mm}\end{array}$ \\
\hline
\end{tabular}

*Zimmermann식[4]을 이용하여 KTX $300 \mathrm{~km} / \mathrm{h}$ 에 대한 동적윤중 값 산정

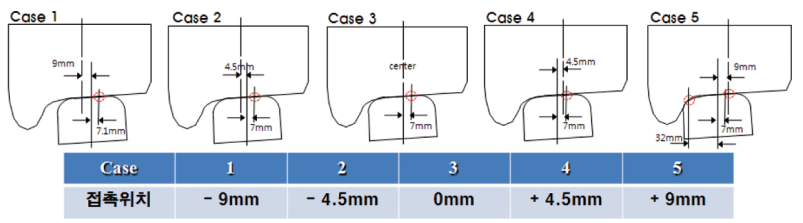

Fig. 2 Analysis requirement according to rail and wheel contact positions

촉점을 변화시킨다. 차륜내측간 거리 $1,355 \mathrm{~mm}$, 궤간 $1,435 \mathrm{~mm}$, 차륜 플랜지 폭 $32.5 \mathrm{~mm}$ 를 기준으로 할 경우 레일중앙으로 부터 좌우로 최대 $15 \mathrm{~mm}$ 까지 이동할 수 있으나, 기존 연구 결과[6]와 같이 $9 \mathrm{~mm}$ 까지 이동하는 것으로 가정하여 접촉응 력 변화를 해석하였다. 이에 따라 차륜-레일 접촉위치에 따 른 해석조건을 Fig. 2와 같이 산정하고 차륜-레일 접촉위치 에 따른 매개변수를 Case 1 5까지로 나타내었다.

\subsection{2 접촉압력 해석결과}

Fig. 3 은 차륜이 레일안쪽으로 $9 \mathrm{~mm}$ 이동한 case 1 의 경 우와 레일 바깥쪽으로 $9 \mathrm{~mm}$ 이동한 case 5 에 대한 해석결 과를 나타낸다. 차륜이 중앙에서 내외측으로 이동할 때 차 륜은 접촉위치가 변화하지만, 레일은 거의 일정한 위치에서 접촉이 발생하였다. 이는 기존연구결과[6]와 동일한 경향인 것으로 나타났다. 또한, 차륜이 중앙에서 외측으로 $9 \mathrm{~mm}$ 이 동하였을 때(Case5)에서 2점 접촉이 발생(차륜 플랜지와 레 일측면 접촉)하였다.

Fig. 4는 접촉위치(case 1 5)별 하중 $(85 \mathrm{kN}, 135 \mathrm{kN})$ 에 따 른 레일길이방향(longitudinal)과 횡방향(lateral)의 접촉압력

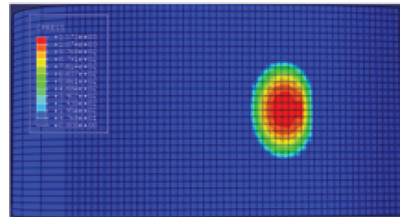

(a) Case 1(Load: $85 \mathrm{kN}$ )

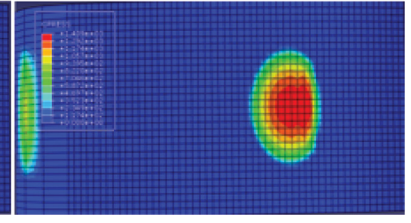

(b) Case 5(Load : $138 \mathrm{kN})$
Fig. 3 Result of contact pressure on FEM analysis 


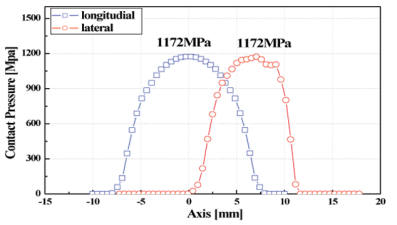

(a) Case 1(Load: $85 \mathrm{kN}$ )

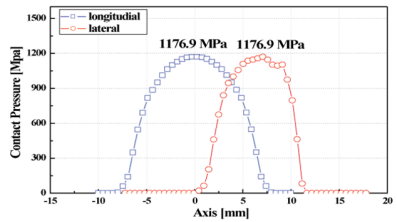

(c) Case 2(Load: $85 \mathrm{kN}$ )

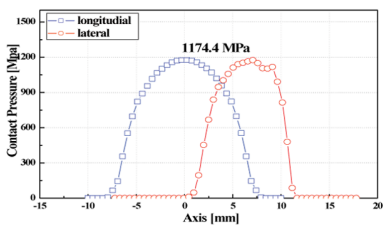

(e) Case 3(Load: $85 \mathrm{kN}$ )

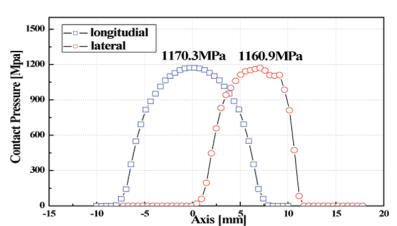

(g) Case 4(Load: $85 \mathrm{kN}$ )

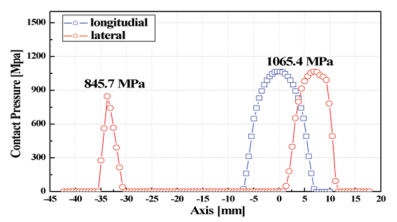

(i) Case 5 (Load: $85 \mathrm{kN})$

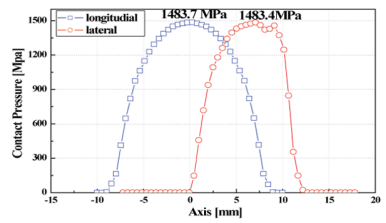

(b) Case 1(Load: $138 \mathrm{kN}$ )

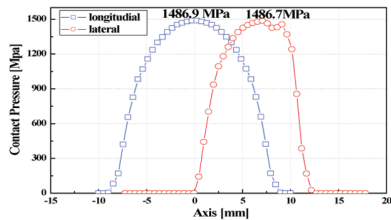

(d) Case 2(Load: $138 \mathrm{kN}$ )

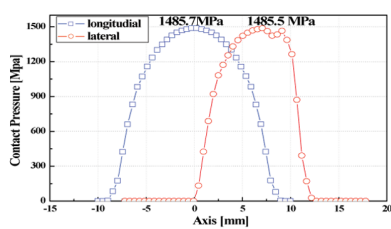

(f) Case 3(Load: $138 \mathrm{kN}$ )

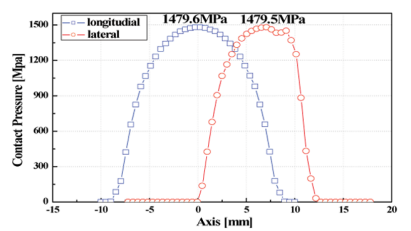

(h) Case 4(Load: $138 \mathrm{kN}$ )

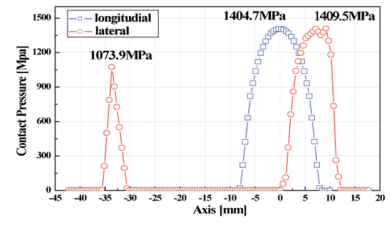

(j) Case 5(Load: $138 \mathrm{kN}$ )

Fig. 4 Result of contact pressure on FEM analysis

해석결과를 나타낸다. 차륜과 레일이 중앙에서 접촉하는 case 3 의 경우 $85 \mathrm{kN}$ 에 대한 최대 접촉압력은 $1,174.4 \mathrm{MPa}$ 이었고, $138 \mathrm{kN}$ 에 대한 최대 접촉압력은 $1,485.7 \mathrm{MPa}$ 로 나타났으며, 내측으로 $4.5 \mathrm{~mm}$ 이동한 case 2 의 경우에는 각각 $1,176.9$ $\mathrm{MPa}$ 와 $1,486.9 \mathrm{MPa}$ 로 가장 크게 나타났다. 즉, $\mathrm{KTX}$ 차륜과 UIC60레일의 접촉압력은 차륜이 레일중앙에서부터 내측으 로 $4.5 \mathrm{~mm}$ 이동하는 범위에서 가장 크게 발생하며, 레일표면 에서는 약 $840 \sim 1500 \mathrm{MPa}$ 범위의 접촉압력이 발생하는 것으 로 분석되었다. 또한, KTX 정적윤중에 비해 $300 \mathrm{~km} / \mathrm{h}$ 에 대 한 동적윤중 적용 시 레일표면 접촉압력은 약 $25 \%$ 이상 증 가하는 것으로 분석되었다.

\section{3. 차륜-레일 구름접촉피로시험}

\section{1 구름접촉피로시험 방법}

$\mathrm{RCF}$ (Rolling Contact Fatigue)시험을 위한 차륜 및 레일

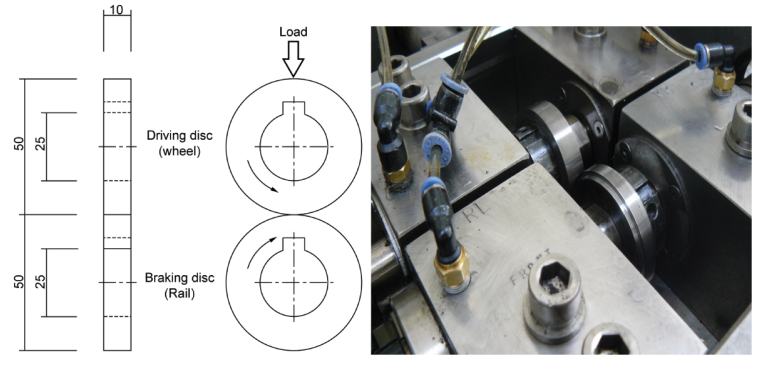

Fig. 5 Rail and wheel specimens

Table 2 Properties of rail and wheel specimens

\begin{tabular}{c|c|c|c}
\hline & Normal rail & Heated rail & Wheel \\
\hline \hline Type & UIC60 & UIC60 & SSW-Q1R \\
\hline Symbol & NR & HR & W \\
\hline $\begin{array}{c}\text { Hardness } \\
(\text { HV) }\end{array}$ & 260 & 360 & 350 \\
\hline
\end{tabular}

디스크 시편의 제원은 Table 2 와 같다. 대상 시편은 국내 고 속철도에서 사용중인 레일의 종류와 같으며, 일반 모재부레 일과 열처리레일은 UIC60을 대상으로 하였다. 열처리레일 의 경우 UIC60 모재부 레일에 열처리를 하여 일반적인 열 처리레일과 동일한 특성을 가지도록 제작하였으며, 시험조 건으로 레일의 마모 및 구름접촉피로에 가혹한 조건을 설정 하기 위해 슬립비를 $-1 \%$ 로 한 시험조건을 설정하였으며, 균 열 및 손상은 진동신호를 측정하여 진동신호가 어느 수준이 상이면 시험이 정지하도록 제어하고, 반복횟수 5 만회 마다 시험기를 정지시켜 광학현미경으로 표면상태를 관찰하였으 며, 일정 반복횟수에 도달한 시편에 대해서는 시편을 가공 하여 마이크로 비커스 경도시험을 실시하였다.

\section{2 레일표면 상태 검토}

구름접촉피로시험 후 일반 모재부레일(NR), 열처리레일 (HR) 시편에 대하여 레일에 적용한 접촉압력(900, 1200, $1500 \mathrm{MPa}$ )에 따른 각 시편의 표면상태 변화 및 손상 발생특 성을 고배율( 100 배율) 광학현미경을 이용하여 관찰하였다.

구름접촉피로시험 후 동일한 반복횟수 $3.0 \times 10^{5}$ 회에서 각 기 다른 접촉압력 $900,1200,1500 \mathrm{MPa}$ 으로 일반레일과 열 처리 레일의 표면상태를 검토한 결과, 두 시편의 표면에 구

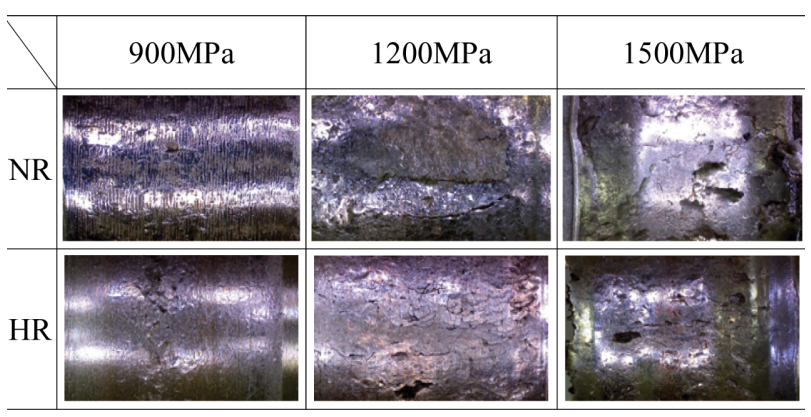

Fig. 6 Surface condition on normal and heated rail after RCF test 
름방향의 직각방향으로 변형경화에 따른 쉘링(shelling, 변형 경화층) 현상과 기존 모재재질의 경계부가 분리되어 떨어져 나가는 두부면 박리(surface flaking) 및 스폴링(spalling)현상이 발생하였다. 또한, 동일한 접촉압력에서 열처리레일의 표면 상태가 일반레일의 표면상태보다 미세하게 안정되어 있는 것 으로 나타났으며, 이는 열처리레일 경도가 일반레일 경도보 다 크기 때문이라고 판단된다.

\section{3 레일표면 경도변화}

구름접촉피로시험 후 접촉압력 $(900,1200,1500 \mathrm{MPa})$ 에 따 른 표면경도변화 수준을 평가하고, 반복횟수에 따른 레일의 경화 진전량을 확인하기 위하여 마이크로 비커스 경도시험 을 수행하였다. 마이크로 비커스 경도시험은 레일의 최적연 마량을 결정하는데 매우 중요한 시험방법(KS B 0811)으로

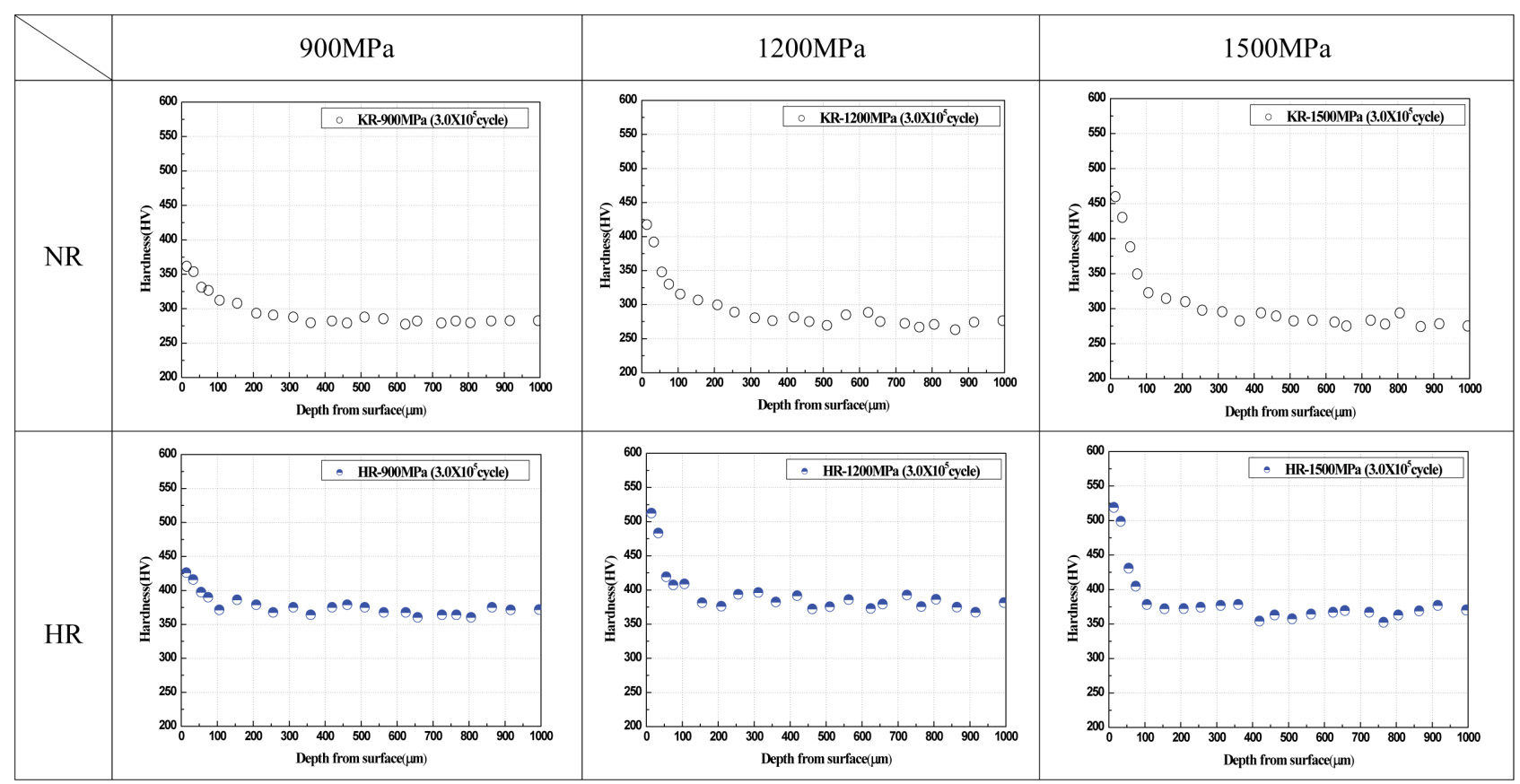

Fig. 7 Result of normal and heated rail hardness on different depth

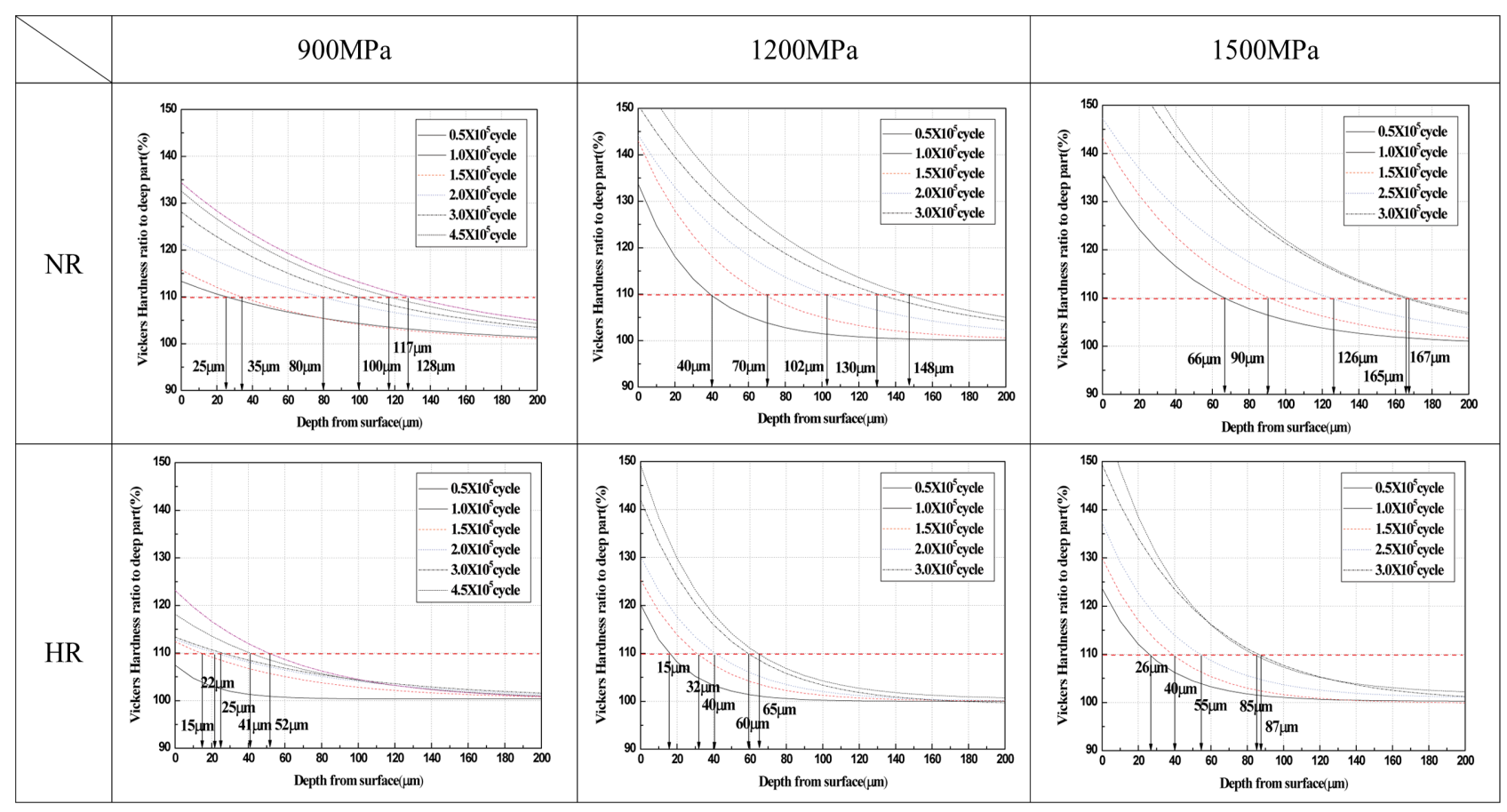

Fig. 8 Analysis of normal and heated rail hardness according to repeated cycles and contact pressure 
사용되고 있으며, 시험하중은 HV $0.5(1.961 \mathrm{~N})$ 으로 산정하였 다. Fig. 7은 접촉압력 및 반복횟수에 따른 경도 변화를 레 일종별로 나타낸 결과이며, 3 회씩 측정한 경도값을 평균하 여 나타내었다.

일반 모재부레일의 경우, 반복횟수 및 접촉압력 증가에 따 라 가공 경화층 깊이가 증가하는 것으로 나타났으며, 접촉 표면의 경도는 심부경도 대비 최대 약 1.6 배 증가하는 것으 로 분석되었다. 열처리레일의 경우에도 접촉압력의 증가에 따라 가공 경화층의 깊이가 증가하는 것으로 나타났으며, 일 반 모재부레일보다 초기 경도값이 증가하는 것으로 나타났 다. 또한, 시편 모두 접촉면으로부터 약 $200 \mu \mathrm{m}$ (약 $0.2 \mathrm{~mm}$ ) 이상 떨어진 지점에서 심부 경도값과 비슷한 수준으로 점차 수렴해 가는 것으로 나타났다.

\section{4. 차륜-레일 구름접촉피로시험결과 분석}

\section{1 레일심부대비 경도변화 분석}

일반 모재부레일과 열처리레일에 대한 표면경도변화를 분 석하기 위해서 레일표면 깊이별 경도값을 심부 대비 경도비 로 변환하고, 레일표면 경도가 심부대비 $95 \% \sim 110 \%[3,4]$ 수 준을 유지하도록 레일연마량 기준치를 설정하여 분석하였다. Fig. 8은 레일종별 접촉압력에 따른 레일표면 깊이별 심부 대비 경도비를 나타낸다.

Fig. 8에서 일반레일과 열처리레일 모두 반복횟수와 접촉 압력이 높을수록 심부대비 경도비가 증가하는 것으로 나타 났으며, 이러한 결과는 차륜과 레일의 접촉횟수가 많거나 접 촉압력이 증가하게되면 레일에서 발생하는 표면의 경화가 빠

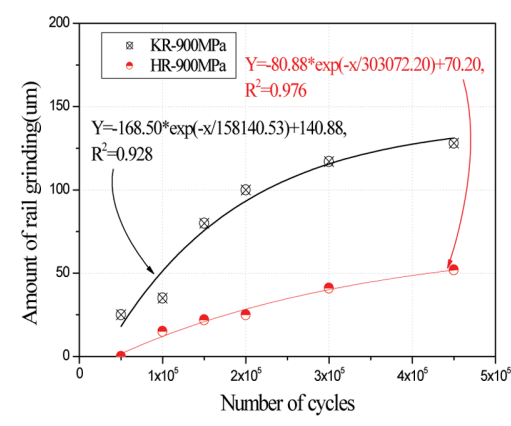

(a) Contact pressure $900 \mathrm{MPa}$

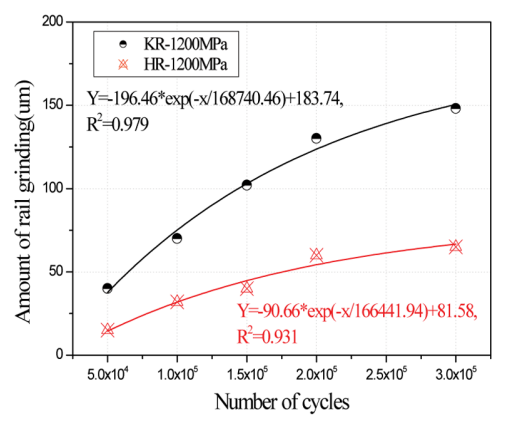

(b) Contact pressure $1200 \mathrm{MPa}$

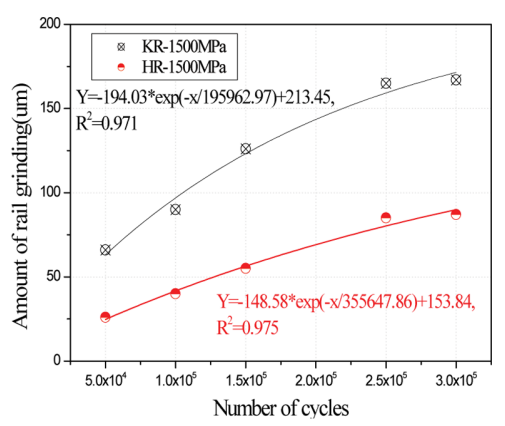

(c) Contact pressure $1500 \mathrm{MPa}$

Fig. 9 Analysis on amount of normal and heated rail grinding according to repeated cycles and contact pressure

Table 3 Result on amount of normal and heated rail grinding according to repeated cycles and contact pressure

\begin{tabular}{|c|c|c|c|c|c|c|c|}
\hline & \multirow{2}{*}{ Contact pressure } & \multicolumn{2}{|c|}{$900 \mathrm{MPa}$} & \multicolumn{2}{|c|}{$1200 \mathrm{MPa}$} & \multicolumn{2}{|c|}{$1500 \mathrm{MPa}$} \\
\hline & & Measured & Regression & Measured & Regression & Measured & Regression \\
\hline \multirow{8}{*}{$\begin{array}{c}\text { Normal } \\
\text { Rail } \\
\text { (NR) }\end{array}$} & $4.5 \times 10^{5}$ cycles & $128 \mu \mathrm{m}$ & $131 \mu \mathrm{m}$ & - & $170 \mu \mathrm{m}$ & - & $194 \mu \mathrm{m}$ \\
\hline & $3.0 \times 10^{5}$ cycles & $117 \mu \mathrm{m}$ & $116 \mu \mathrm{m}$ & $148 \mu \mathrm{m}$ & $151 \mu \mathrm{m}$ & $167 \mu \mathrm{m}$ & $171 \mu \mathrm{m}$ \\
\hline & $2.5 \times 10^{5}$ cycles & - & $106 \mu \mathrm{m}$ & - & $139 \mu \mathrm{m}$ & $165 \mu \mathrm{m}$ & $159 \mu \mathrm{m}$ \\
\hline & $2.0 \times 10^{5}$ cycles & $100 \mu \mathrm{m}$ & $93 \mu \mathrm{m}$ & $130 \mu \mathrm{m}$ & $124 \mu \mathrm{m}$ & - & $144 \mu \mathrm{m}$ \\
\hline & $1.5 \times 10^{5}$ cycles & $80 \mu \mathrm{m}$ & $79 \mu \mathrm{m}$ & $102 \mu \mathrm{m}$ & $103 \mu \mathrm{m}$ & $126 \mu \mathrm{m}$ & $123 \mu \mathrm{m}$ \\
\hline & $1.0 \times 10^{5}$ cycles & $35 \mu \mathrm{m}$ & $51 \mu \mathrm{m}$ & $70 \mu \mathrm{m}$ & $75 \mu \mathrm{m}$ & $90 \mu \mathrm{m}$ & $97 \mu \mathrm{m}$ \\
\hline & $0.5 \times 10^{5}$ cycles & $25 \mu \mathrm{m}$ & $18 \mu \mathrm{m}$ & $40 \mu \mathrm{m}$ & $38 \mu \mathrm{m}$ & $66 \mu \mathrm{m}$ & $63 \mu \mathrm{m}$ \\
\hline & $\begin{array}{c}\text { Depth of grinding } \\
\text { ( } 20 \mathrm{MGT}=1,176,470 \text { cycles })\end{array}$ & - & $\begin{array}{c}141 \mu \mathrm{m} \\
(0.141 \mathrm{~mm})\end{array}$ & - & $\begin{array}{c}184 \mu \mathrm{m} \\
(0.184 \mathrm{~mm})\end{array}$ & - & $\begin{array}{c}212 \mu \mathrm{m} \\
(0.212 \mathrm{~mm})\end{array}$ \\
\hline \multirow{8}{*}{$\begin{array}{l}\text { Heated Rail } \\
\text { (HR) }\end{array}$} & $4.5 \times 10^{5}$ cycles & $52 \mu \mathrm{m}$ & $52 \mu \mathrm{m}$ & - & $76 \mu \mathrm{m}$ & - & $112 \mu \mathrm{m}$ \\
\hline & $3.0 \times 10^{5}$ cycles & $41 \mu \mathrm{m}$ & $40 \mu \mathrm{m}$ & $65 \mu \mathrm{m}$ & $67 \mu \mathrm{m}$ & $87 \mu \mathrm{m}$ & $90 \mu \mathrm{m}$ \\
\hline & $2.5 \times 10^{5}$ cycles & - & $35 \mu \mathrm{m}$ & - & $61 \mu \mathrm{m}$ & $85 \mu \mathrm{m}$ & $80 \mu \mathrm{m}$ \\
\hline & $2.0 \times 10^{5}$ cycles & $25 \mu \mathrm{m}$ & $28 \mu \mathrm{m}$ & $60 \mu \mathrm{m}$ & $54 \mu \mathrm{m}$ & - & $69 \mu \mathrm{m}$ \\
\hline & $1.5 \times 10^{5}$ cycles & $22 \mu \mathrm{m}$ & $21 \mu \mathrm{m}$ & $40 \mu \mathrm{m}$ & $45 \mu \mathrm{m}$ & $55 \mu \mathrm{m}$ & $56 \mu \mathrm{m}$ \\
\hline & $1.0 \times 10^{5}$ cycles & $15 \mu \mathrm{m}$ & $12 \mu \mathrm{m}$ & $32 \mu \mathrm{m}$ & $32 \mu \mathrm{m}$ & $40 \mu \mathrm{m}$ & $42 \mu \mathrm{m}$ \\
\hline & $0.5 \times 10^{5}$ cycles & $0 \mu \mathrm{m}$ & $2 \mu \mathrm{m}$ & $15 \mu \mathrm{m}$ & $14 \mu \mathrm{m}$ & $26 \mu \mathrm{m}$ & $25 \mu \mathrm{m}$ \\
\hline & $\begin{array}{c}\text { Depth of grinding } \\
\text { ( } 20 \mathrm{MGT}=1,176,470 \text { cycles })\end{array}$ & - & $\begin{array}{c}68 \mu \mathrm{m} \\
(0.068 \mathrm{~mm})\end{array}$ & & $\begin{array}{c}82 \mu \mathrm{m} \\
(0.082 \mathrm{~mm})\end{array}$ & - & $\begin{array}{c}148 \mu \mathrm{m} \\
(0.148 \mathrm{~mm})\end{array}$ \\
\hline
\end{tabular}


르게 진전됨을 의미한다. 본 구름접촉피로시험에는 최대 반 복횟수가 45만회로 실제 고속철도에서 발생하는 연간 누적 통과톤수 약 2 천만톤 $(1,176,470 \mathrm{cycles})$ 에 비해 작기 때문에 심부대비 경도비가 $110 \%$ 에 해당하는 값을 연마량으로 보고 접촉압력에 따른 표면경화층 발생 경향을 분석하였다.

\section{2 레일의 심부대비 경도변화 회귀분석}

실제 누적통과톤수에 따른 레일연마량을 산정하기 위해 레 일종별 접촉압력에 따른 연마량에 대한 회귀분석을 수행하 였으며, 그 결과는 Table 3, Fig. 9와 같다. Table 3에는 Fig. 9의 회귀분석식을 통해 국내 고속철도 1 년간 통과톤수인 약 2 천만톤 $(1,176,470 \mathrm{cycles})$ 에 해당하는 연마량을 예측하였다. 일반 모재부레일의 경우 약 $0.2 \mathrm{~mm}$ 이상 $/ 2$ 천만톤, 열처리레일 의 경우 약 $0.15 \mathrm{~mm}$ 이상 $/ 2$ 천만톤을 연마할 경우 차륜과 레 일의 구름접촉에 의해 발생하는 레일표면의 경화층을 연마 할 수 있는 것으로 분석되었다.

\section{5. 결 론}

본 연구에서는 고속철도 레일에서 발생할 수 있는 접촉압 력을 실제 $\mathrm{KTX}$ 동력차 차륜과 UIC60레일의 동일한 크기 와 물성치로 $\mathrm{ABAQUS}$ 를 이용하여 모델링 한 후, 정적윤중 과 $300 \mathrm{~km} / \mathrm{h}$ 에 대한 동적윤중에 대하여 차륜의 위치별 접촉 압력을 산정하고, 산정된 접촉압력에 대한 구름접촉피로시 험을 통해 반복횟수 및 접촉압력에 따른 레일표면경화층을 분석하였으며, 본 연구를 통해 도출된 결론은 다음과 같다.

$\mathrm{KTX}$ 동력차 차륜과 UIC60레일의 접촉위치별 접촉압력의 변화를 확인한 결과, 레일에서 발생하는 접촉압력은 $\mathrm{KTX}$ 차 륜이 레일중앙과 레일내측 약 $4.5 \mathrm{~mm}$ 범위에서 가장 크게 발 생하는 것으로 분석되었으며, $\mathrm{KTX}$ 정적윤중 $(85 \mathrm{kN})$ 에 대한 최대접촉압력은 약 $1200 \mathrm{MPa}$ 이었으며, $\mathrm{KTX} 300 \mathrm{~km} / \mathrm{h}$ 에 대 한 동적윤중 $(138 \mathrm{kN})$ 재하 시 최대접촉압력은 약 $1500 \mathrm{MPa}$ 이 발생하는 것으로 분석되었다. 또한, 정적윤중에 비해 동 적윤중 적용 시 최대접촉압력이 약 $25 \%$ 이상 증가하는 것으 로 나타났다.

구름접촉피로시험(RCF)를 통해 일반레일과 열처리레일의 표면상태와 균열발생여부를 검토한 결과, 접촉압력 및 반복 횟수의 증가에 따라 레일표면에서 소성변형 현상(경화층)이
발생하였으며, 열처리레일에 비해 표면경도가 낮은 일반레 일에서 소성변형 현상이 크게 발생하는 것으로 나타났다. 또 한, 접촉압력 및 반복횟수의 증가는 레일의 표면경도를 증 가시키고, 일반레일에 비해 열처리레일이 접촉압력 및 반복 횟수의 증가에 따라 표면경도 변화가 약 $20 \sim 40 \%$ 정도 낮은 것으로 분석되었다.

UIC60 일반레일과 열처리레일의 경우 $300 \mathrm{~km} / \mathrm{h}$ 로 주행하 는 $\mathrm{KTX}$ 에 의한 레일연마를 1 년 주기로 1 회 실시하는 것으 로 가정한다면, 일반레일의 연마량은 $0.2 \mathrm{~mm} / 2$ 천만톤, 열처 리레일의 연마량은 $0.15 \mathrm{~mm} / 2$ 천만톤이 적정하다고 판단된다.

\section{후 기}

본 논문은 국토해양부 차세대고속철도기술개발사업의 연 구비지원으로 수행되었습니다. 관계자분들께 감사드립니다.

\section{참고문헌}

[1] M. C. Kim (2006) The Report for Establishment of Rail Grinding Criteria, KRRI, Korail.

[2] M. Ishida (1999) Experimental study on the effect of preventive grinding on RCF defects of Shinkansen rails, IHHA'99 STS-conference, pp. 511-516.

[3] M. C. Kim, T. K. Kang (2008), Rail Grinding Criteria of Kyeong-Bu High-Speed Line for Effective Rail Maintenance, Journal of the Korean Society for Railway, 11(3), pp. 272-279.

[4] D. Y. Sung, D. C. Go, Y. G. Park, S. Y. Kong (2010) Experimental Study for Establishing Rail Grinding Period in the Urban Railway, Journal of the Korean Society for Railway, 13(4), pp. 447-454.

[5] Coenraad Esveld (2001) Modern Railway Track, MRT-Productions, pp. 23-33, pp. 71-90.

[6] H. Y. Choi, D. H. Lee, W. H. You, J. S. Lee (2010) Wheel-Rail Contact Analysis considering the Deformation of Wheel and Axle, Journal of the Korean Society of Precision Engineering, 27(8).

접수일(2011년 12월 13일), 수정일(2012년 1월 16일), 게재확정일(2012년 1월 30일) 